\section{Kozyk V., Mrykhina 0., Mirkunova T.}

\title{
JUSTIFICATION OF METHODOLOGICAL APPROACHES TO ASSESSING THE TECHNOLOGY TRANSFER READINESS
}

Досліджено методи і моделі економічного оцінювання трансферу технологій. Запропоновано модель оцінювання рівня готовності технологій до трансферу, що складається з п'яти оцінювальних блоків (споживча щінність; конкурентоспроможність; технологічна готовність; витратність; ризиковість). Розроблено методичний інструментарій для оцінювання рівня готовності технологій до трансферу на засадах теорії надійності ієрархічно розгалужених систем.

Ключові слова: методи і моделі економічного оцінювання, трансфер технологій, теорія надійності ієрархічно розгалужених систем.

\section{Introduction}

One of the main factors of modern technological progress of the leading countries of the world is increasing the level of intellectualization of technologies while reducing their life cycle. Efficiency in the implementation of research and development (R\&D) results in the emergence of business opportunities, which in turn generate demand for new technologies. The chain $\ll R \& D \rightarrow$ commercialization of $R \& D$ results» is characterized by a significant reduction in the time period in all industries. Due to the modern synergistic interaction of digital, physical and biological technologies, not only the nature of technological progress is changing, but also approaches to human development in general. Trends of world analytics [1,2] indicate the rapid development of artificial intelligence, high technologies and methods of processing databases in all technological areas. These phenomena and trends have necessitated a review by the countries of the world of existing approaches to the development, assessment and technology transfer.

In the context of this, one of the primary tasks is development of methods for assessing the readiness of technologies for transfer. Justification of the level of technology readiness for transfer should reflect, on the one hand, the commercial characteristics of technology, on the other - innovative, technological. The technology that is prepared for the transfer must meet market requirements and stimulate technological progress.

The difficulty in assessing the level of technology readiness for a transfer is that technologies basically contain objects of intellectual property rights (OIPR), which are considered to be one of the most difficult tasks of the modern economy. However, the intellectualization of technology is an objective and irreversible phenomenon, it calls for the development of new economic tools for working with technologies, approaches to the accounting of the OIPRs in their composition, and the forecasting of market effects from technology.

Taking into account the mentioned, topicality of the problematic of methodical support of technology readiness for transfer is indicated by the fact that the speed of transfer and the efficiency of technological development of the state as a whole depend on the degree of its validity.
The active application of the concept of open innovation by the community of developed countries of the world actualizes the problems of technology transfer in a new light, namely, the transfer of technologies from universities to the business environment is a key role. Scientific and practical importance is the development of methodological approaches to assessing the readiness of technologies for transfer, taking into account the specifics of university R\&D.

\section{The object of research and its technological audit}

The subject of this work is a set of theoretical and applied bases for assessing the readiness level of technologies for transfer, the object are methodological approaches to assess the readiness level of technologies for transfer.

According to [3], in recent years, the transfer of technology from the university environment has become an increasingly important source of regional economic development and university revenues, far exceeding other types of technology transfer.

The importance of technology transfer from universities to the business environment is emphasized by attention to it in the documents of world organizations engaged in research of technological development of countries. Versatile aspects of technology transfer for all components of the country's competitiveness index, which is annually developed by the World Economic Forum and covered in [1]. In particular, in the 12th component of the «Innovation» of this index, attention is focused on the parameters of technology transfer originating from the university environment. In the «Global Report on Information Technology 2016» [2] of this organization, considerable attention has been paid to the engine of modern technology transfer and the confirmation of the role of high-tech enterprises created by universities. The influence of universities manifests itself both in carrying out innovative $\mathrm{R} \& \mathrm{D}$ and the implementation of their results, and in creating an innovative ecosystem.

In the world practice, universities are considered to be powerful scientific and technological centers of the countries. However, in Ukraine in 2015 in the sector of 
Ukrainian higher education, about $18.5 \%$ of scientific and technical works [4] were performed, which is a relatively low value, compared with the developed countries of the world. In general, $22 \%$ of scientific and technical works related to the use of inventions were performed in the higher education sector of Ukraine in the same year, $27.9 \%$ with the creation of resource-saving technologies, and $23 \%$ with the development of new materials [4]. But, it is the higher educational institutions that provide the largest part in Ukraine of the total number of applications for the issuance of protection documents.

The number of works that were carried out by scientific organizations of Ukraine in 2015 was 41.1 thousand, of which more than two thirds were introduced into production or characterized by other forms of transfer. Of the total number of scientific papers [4]:

$16.5 \%$ - to create new methods and theories, more than half of which were used in further work;

$9.9 \%$ is aimed at creating new types of products;

$41.9 \%$ - new types of equipment;

$7.5 \%$ - new technologies;

$45.4 \%$ - resource-saving technologies;

$5.8 \%$ - new varieties of plants, animal breeds;

$2.2 \%$ - new types of materials.

Taking into account the above, the problem becomes important - why, at a sufficiently high level of the innovative potential of Ukraine, the technology transfer takes place at a slow pace. One of the ways to solve it is development of economic approaches to assessing the readiness level of technologies for transfer. After all, it is often from the objective determination of the readiness of technology for transfer that its efficiency depends.

\section{The aim and objectives of research}

The aim of the work is substantiation of methodological approaches to assessing the readiness level of technologies for transfer. This aim led to the establishment and achievement of a number of tasks, in particular:

1. To analyze existing methods and models of economic evaluation of technology.

2. To propose a model for assessing the readiness of technologies for transfer.

3. To develop a toolkit for assessing the technology transferability.

\section{Research of existing solutions of the problem}

The complexity of modern market demand for technology assessment is growing faster than the corresponding methods are being developed for this. World scientists and practitioners have developed a significant number of manuals and models of technology assessment. In particular, the Oslo Manual (2002), the Frascati Manual (2015), the Canberra Manual (1995), the NASA Model, the S. Mueeg Model for the Preparation of Process Products, the J. Berman and G. Valander Model, the R. J. Cooper's «StageGate» model, B. Bozeman model of the conditional efficiency of the technology transfer the like. However, in Ukrainian realities it is not always possible to apply these developments, since they are more in line with the legal, socio-economic, political features of their countries of origin.
The work of many scientists is devoted to the problem of research methods of economic evaluation of innovative technologies, in particular the readiness of technologies for transfer [5-21]. The findings of these scientists are valuable in terms of using separate provisions for technology assessment. However, for the application in Ukrainian conditions, the proposed developments need substantial adaptation.

The analysis of the studies has shown that mainly attention is paid to specific, specialized aspects of technology assessment, in particular:

- [22-25] are devoted to technology assessment in the context of their management;

- approaches to the evaluation of intellectual capital are investigated in [26, 27];

- the authors of the works [28-31] are engaged in studies of the economic evaluation of intellectual-innovative technologies. However, the models proposed by them are predominantly local or sectoral in nature.

In spite of the substantial backlog in the field of methodological support for technology transfer, at present there is no necessary and sufficient number of developed methodological approaches to assessing the readiness level of technologies for transfer.

\section{Methods of research}

To achieve this aim and solve established problems, scientific methods are used: system method, grouping method; methods of analysis and synthesis; method of structural and logical analysis, method of mathematical modeling, graphical method.

\section{Research results}

Among the most important aspects that determine the future success of technology transfer is the rationale for choosing its option, which is preceded by an assessment of the readiness of technology for transfer. For this purpose, such model is proposed (Fig. 1).

The model for assessing the level of technology readiness for transfer should provide an understanding of the subject of technology transfer as the relationship between its participants in the creation and transfer of value added in the form of technology, taking into account the impact of world technological development.

The proposed model is a new concept for assessing the readiness level of technologies for transfer and provides a new approach to the justification of its results. Partially this problem can be solved by applying the method of constructing polygons. Thus, during this time there may be deviations associated with different rates of development of the technology according to the described blocks. For example, for the period of technology development (the block of «assessing the technological readiness of technology»), technological changes can occur that will lead to changes in other blocks (the block for «estimating the cost of technology», etc.). As a consequence, there is a need for rapid adjustments to technology assessments at appropriate stages.

Given that the proposed model for assessing the readiness level of technologies for transfer is a multi-level system, it is necessary to understand the nature of the processes in it and to take into account destabilizing and favorable factors in technology assessment. 


\begin{tabular}{|c|c|c|c|c|c|}
\hline \multicolumn{6}{|c|}{ I level: determination of technology transferability } \\
\hline $\begin{array}{l}\text { Components of } \\
\text { technology assess- } \\
\text { ment }\end{array}$ & $\begin{array}{l}\text { Consumer value of } \\
\text { technology }\end{array}$ & $\begin{array}{l}\text { Competitiveness of } \\
\text { technology }\end{array}$ & $\begin{array}{l}\text { Technological readi- } \\
\text { ness of technology }\end{array}$ & Cost of technology & $\begin{array}{l}\text { Riskiness of tech- } \\
\text { nology }\end{array}$ \\
\hline \multirow[b]{2}{*}{$\begin{array}{l}\text { 1 Stage of techno- } \\
\text { logy readiness - } \\
\text { conceptual }\end{array}$} & \multicolumn{5}{|c|}{ Justification of the feasibility of technology development } \\
\hline & $\begin{array}{l}\text { 1. Assessment of key } \\
\text { technology compe- } \\
\text { tencies }\end{array}$ & $\begin{array}{l}\text { 1. Assessment of the } \\
\text { market (markets) of } \\
\text { technology }\end{array}$ & $\begin{array}{l}\text { 1. Formulation of } \\
\text { the hypothesis for } \\
\text { determining the } \\
\text { subject of research } \\
\text { work }\end{array}$ & $\begin{array}{c}\text { 1. Characteristics of } \\
\text { the technology as } \\
\text { OIPR }\end{array}$ & $\begin{array}{l}\text { 1. Assessment of } \\
\text { risks inherent in } \\
\text { the development } \\
\text { of technology }\end{array}$ \\
\hline \multirow{8}{*}{$\begin{array}{l}2 \text { Stage of techno- } \\
\text { logy readiness - } \\
\text { development of } \\
\text { technology }\end{array}$} & \multicolumn{5}{|c|}{ Investigation of the technology market and $R \mathcal{E} D$} \\
\hline & $\begin{array}{l}\text { 2. Analysis of at- } \\
\text { tributes of consumer } \\
\text { value of technology }\end{array}$ & $\begin{array}{l}\text { 2. Evaluation of com- } \\
\text { petitors }\end{array}$ & $\begin{array}{l}\text { 2. Research and } \\
\text { development work } \\
\text { (R \& D) }\end{array}$ & $\begin{array}{c}\text { 2. Assessment of the } \\
\text { cost of the economic } \\
\text { justification of technol- } \\
\text { ogy }\end{array}$ & $\begin{array}{l}\text { 2. Market risk } \\
\text { assessment }\end{array}$ \\
\hline & \multicolumn{5}{|c|}{ Technology development } \\
\hline & $\begin{array}{l}\text { 3. Definition of } \\
\text { the life cycle of } \\
\text { consumer value of } \\
\text { technology }\end{array}$ & $\begin{array}{l}\text { 3. Forming a map of } \\
\text { strategic economic } \\
\text { zones }\end{array}$ & $\begin{array}{l}\text { 3. Experimental } \\
\text { design work }\end{array}$ & $\begin{array}{c}\text { 3. Establishment of } \\
\text { patentability and ex- } \\
\text { pediency of technology } \\
\text { patenting }\end{array}$ & $\begin{array}{l}\text { Risk assessment } \\
\text { of failure to com- } \\
\text { plete R \& D }\end{array}$ \\
\hline & $\begin{array}{l}\text { 4. Formation of the } \\
\text { product offer }\end{array}$ & $\begin{array}{l}\text { 4. Study of the legisla- } \\
\text { tive framework for the } \\
\text { regulation of competi- } \\
\text { tive relations }\end{array}$ & $\begin{array}{l}\text { 4. Design prepara- } \\
\text { tion of production }\end{array}$ & $\begin{array}{l}\text { 4. Valuation of technol- } \\
\text { ogy for the purpose of } \\
\text { crediting to the assets } \\
\text { of the enterprise }\end{array}$ & $\begin{array}{l}\text { 4. Risk assess- } \\
\text { ment of the lack } \\
\text { of resource sup- } \\
\text { port for technol- } \\
\text { ogy development }\end{array}$ \\
\hline & $\begin{array}{l}\text { 5. Optimization of } \\
\text { technology con- } \\
\text { sumption price }\end{array}$ & $\begin{array}{l}\text { 5. Formation of a com- } \\
\text { petitive market map }\end{array}$ & $\begin{array}{l}\text { 5. Technological } \\
\text { preparation of pro- } \\
\text { duction }\end{array}$ & $\begin{array}{l}\text { 5. Valuation of tech- } \\
\text { nology for commercia- } \\
\text { lization purposes }\end{array}$ & $\begin{array}{l}\text { 5. Assessment of } \\
\text { patent risk }\end{array}$ \\
\hline & $\begin{array}{l}\text { 6. Justification of } \\
\text { the value proposi- } \\
\text { tion of technology }\end{array}$ & $\begin{array}{l}\text { 6. Assessment of com- } \\
\text { petitive positions of } \\
\text { technology }\end{array}$ & $\begin{array}{l}\text { 6. Organizational } \\
\text { production prepara- } \\
\text { tion }\end{array}$ & $\begin{array}{l}\text { 6. Substantiation of } \\
\text { the organizational and } \\
\text { legal form of techno- } \\
\text { logy transfer }\end{array}$ & $\begin{array}{l}\text { 6. Assessment } \\
\text { of the risk of } \\
\text { certification } \\
\text { impossibility }\end{array}$ \\
\hline & $\begin{array}{l}\text { 7. Establishing } \\
\text { marketing commu- } \\
\text { nications with the } \\
\text { market }\end{array}$ & $\begin{array}{l}\text { 7. Assessment of barri- } \\
\text { ers and opportunities } \\
\text { for market technology } \\
\text { launch }\end{array}$ & $\begin{array}{l}\text { 7. Testing of } \\
\text { technology in pilot } \\
\text { production }\end{array}$ & $\begin{array}{l}\text { 7. Formation of the } \\
\text { price policy of market } \\
\text { technology launch }\end{array}$ & $\begin{array}{l}\text { 7. Risk assess- } \\
\text { ment of inef- } \\
\text { ficient scaling }\end{array}$ \\
\hline \multirow{4}{*}{$\begin{array}{l}3 \text { Stage of technol- } \\
\text { ogy readiness - the } \\
\text { technology is ready } \\
\text { (representation } \\
\text { of the prototype, } \\
\text { research model, } \\
\text { etc.) }\end{array}$} & \multicolumn{5}{|c|}{ Choosing a business form of technology transfer } \\
\hline & $\begin{array}{l}\text { 8. The partnerships } \\
\text { with the technology } \\
\text { transfer enterprise }\end{array}$ & $\begin{array}{l}\text { 8. Quantitative analysis } \\
\text { of the competitive posi- } \\
\text { tions of technology }\end{array}$ & $\begin{array}{l}\text { 8. Preparation of a } \\
\text { research sample for } \\
\text { a business proposal }\end{array}$ & $\begin{array}{l}\text { 8. Accounting for } \\
\text { uncertainties in the } \\
\text { technology transfer }\end{array}$ & $\begin{array}{l}\text { 8. Establishing } \\
\text { threats to trans- } \\
\text { fer technology }\end{array}$ \\
\hline & \multicolumn{5}{|c|}{ Clarification, adjustment } \\
\hline & $\begin{array}{l}\text { 9. Checking, cor- } \\
\text { recting shortcom- } \\
\text { ings and preparing } \\
\text { a report on the } \\
\text { evaluation of the } \\
\text { value proposition of } \\
\text { technology }\end{array}$ & $\begin{array}{l}\text { 9. Clarification and } \\
\text { adjustment of all indi- } \\
\text { cators of technology } \\
\text { competitiveness }\end{array}$ & $\begin{array}{c}\text { 9. Adjustment and } \\
\text { final coordination } \\
\text { of all technological } \\
\text { aspects }\end{array}$ & $\begin{array}{l}\text { 9. Refinement of re- } \\
\text { ceived results and error } \\
\text { correction }\end{array}$ & $\begin{array}{l}\text { 9. Verification } \\
\text { and correction of } \\
\text { all types of tech- } \\
\text { nology risks }\end{array}$ \\
\hline \multicolumn{6}{|c|}{ II level: justification of opportunities for transfer of selected technology } \\
\hline \multirow{3}{*}{$\begin{array}{l}4 \text { Stage of orga- } \\
\text { nizing the techno- } \\
\text { logy transfer }\end{array}$} & $\begin{array}{l}\text { Coordination of as- } \\
\text { pects with partners }\end{array}$ & $\begin{array}{l}\text { Establishing contact } \\
\text { with a potential coun- } \\
\text { terparty }\end{array}$ & $\begin{array}{l}\text { Justification of the } \\
\text { technology market } \\
\text { (technological } \\
\text { aspect) }\end{array}$ & $\begin{array}{c}\text { Organization of patent } \\
\text { protection }\end{array}$ & $\begin{array}{l}\text { Establishment } \\
\text { of options for } \\
\text { legal relations for } \\
\text { OIPR }\end{array}$ \\
\hline & \multicolumn{5}{|c|}{ III level: choice of technology transfer option } \\
\hline & & & echnology transfer & & \\
\hline
\end{tabular}

Fig. 1. Model for assessing the readiness of technology for transfer 
Therefore, an important and promising task is development of such method of assessing the readiness level of technology for transfer, which would give a reasoned conclusion not only in terms of the level of technology readiness, but also showed the nature of the interaction of the model blocks among themselves.

The development of many processes in nature has a tree-like, branched nature, and mathematical models of probabilistic and temporal characteristics of branched systems can be used to study such processes. These are complex systems with a hierarchical structure [32].

From the point of view of the model of assessing the readiness level of technologies for transfer (Fig. 1), as a hierarchically branched structure (there are stages, levels, blocks and stages etc.), for the task set above, it is possible to use developments on the theory of reliability of hierarchically branched systems.

As a scientific discipline, the reliability theory provides for the study and development of methods for ensuring the effectiveness of the operation of objects during their operation, investigating the relationship between performance indicators and reliability. In a broad sense, under the reliability of the system, it means its ability to work without fail during a given time interval. Therefore, the reliability theory is based on the concept of failure - that is, the event, as a result of which there is a complete or partial violation of the system's performance. Within the framework of reliability theory, there are parameters of object reliability, in particular, taking into account various factors of influence.

The conducted research has shown that this theory is suitable for assessing the readiness level of technologies for transfer, because:

- the proposed model (Fig. 1) for assessing the readiness level of technology for transfer is a system (has input and output elements), isotropic with simple subordination, symmetric with branching;

- an assessment of each stage in the blocks of the model reflects a certain level of technology readiness, necessitates the determination of probabilistic assessments of the readiness of technology, can be expressed quantitatively;
- an integrated assessment of the initial parameters of the model shows the level of failures, and in the economic interpretation - the general readiness level of technology for transfer.

Among the possible basic mathematical devices for predicting the reliability of branched systems, the probability theory is singled out. In the case of the developed model (Fig. 1), the determination of probabilistic assessments of the readiness of the technology behind each of the evaluation blocks makes it possible to predict the readiness of the technology at a given level. In turn, this allows the establishment of an integrated readiness level, which will complement the previously formed general conclusion derived from the above polygon model.

To solve the problem, it is necessary to consider such categories of reliability of a branched system, as: generators of functions, recurrence expressions and mathematical expectations of an event. The generator is used for discrete random variables. A discrete random variable is a random variable which value is equal to the product of a random variable by its probability. On the basis of the generating function, a recurrent expression is developed to calculate the probability distribution of the number of working source elements. By recurrent expression, it is possible to determine the probability of failure-free operation of a certain number of output elements of the system. This allows to determine the mathematical expectation, probability distribution and readiness factor of such systems.

The authors of [32] conducted a study of methods for predicting the reliability of branched systems, on the basis of which they concluded that for systems with simple subordination there are no restrictions in constructing generating functions during the investigation of reliability characteristics. To assess the readiness level of technology for transfer using a hierarchically branched system model, such sequence of actions is proposed (Fig. 2).

Let's derive the expressions for the generating function, the recurrence expression and the mathematical expectation for the developed conceptual model for assessing the readiness level of technology for transfer, based on the application of the reliability theory of branched systems. Schematically, a hierarchical system branched to the first level is shown in Fig. 3.

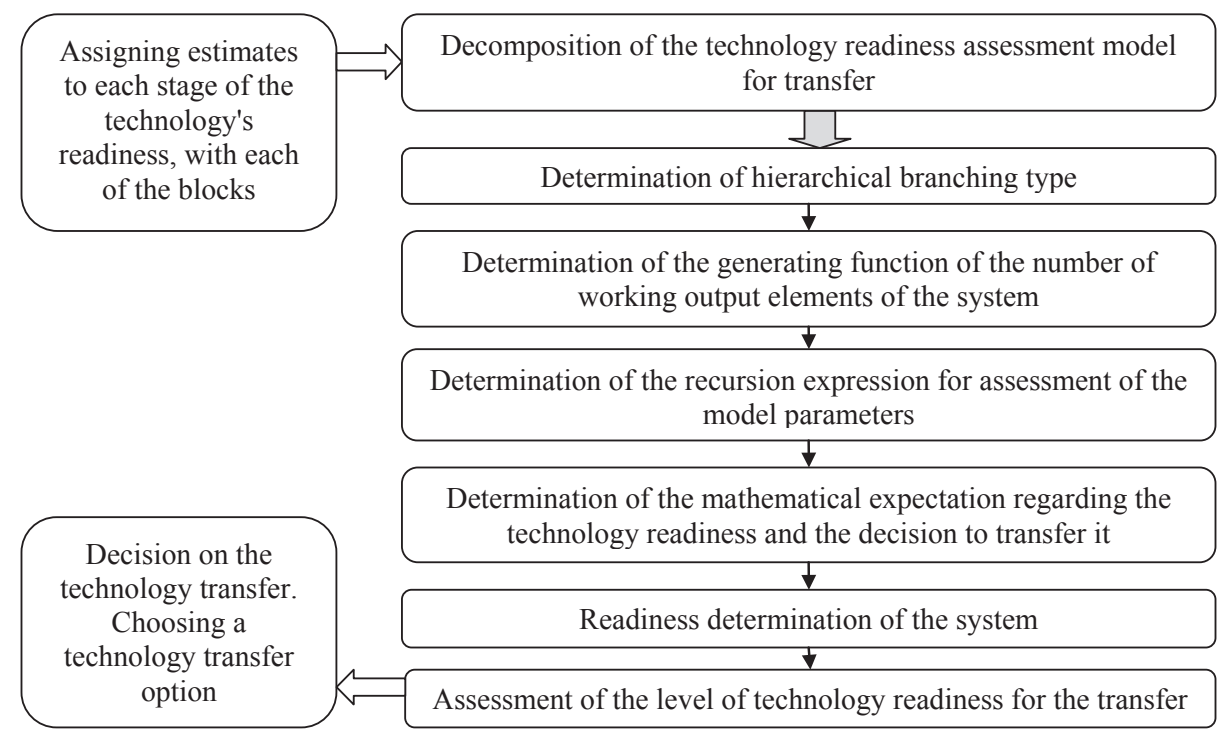

Fig. 2. Sequence of assessment of the level of technology readiness for the transfer 


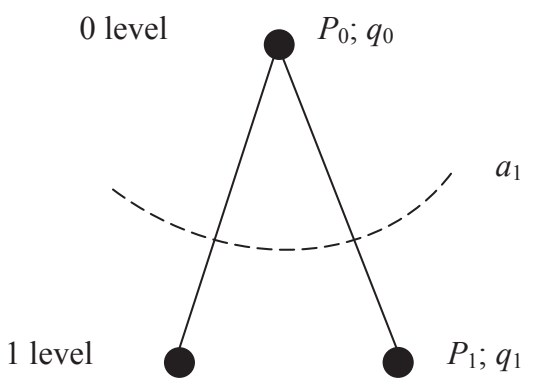

Fig. 3. Hierarchical system, branched to the first level [32]

Let's write the generating function of the number of working output elements of this system:

$$
S_{1}(z)=P_{0}\left(P_{1} z+q_{1}\right)^{a_{1}}+q_{0},
$$

where $P_{0}$ - the probability of work, and $q_{0}$ - the probability of failure of the elements of the system, $z$ - an arbitrary parameter, $a$ - the branching factor.

The element of the first level has, respectively, the value of these probabilities $P_{0}$ and $q_{0}$. The principle of hierarchy is realized here so that the element of the highest level the zero one - in case of failure, removes the element of the lower, the first level from work. Therefore, the work of an element of the first level implies the simultaneous operation of a zero-level element [32].

The low-level elements of this system are the initial elements of the system. As a rule, decomposition is effective at branching from three to six levels. A greater number of levels complicate the assessment by excessive detail.

From the position of reliability analysis of hierarchically branched systems, the proposed model (Fig. 1) is expedient for decomposition into two levels. At the highest level (roots) of the hierarchy is technology, which is evaluated. The following hierarchical levels of the model are distinguished:

- the zero hierarchy level $\left(P_{0}\right)$ where the technology transfer centers (or other similar units of universities) receive technology and justify its transferability. This hierarchy level corresponds to the first level of the concept (Fig. 1);
- the first hierarchy level $\left(P_{1}\right)$ where the possibilities for the transfer of the selected technology are specified (corresponds to the second level of the model (Fig. 1), occurs according to the above five blocks of technology assessment);

- the second hierarchy level $\left(P_{2}\right)$ on which the technology transfer scenario is selected (corresponds to the third level of the concept (Fig. 1). This is schematically shown in Fig. 4.

On the branches $P_{0}-P_{1}$ and $P_{1}-P_{2}$, the elements of the model are placed (the stages of the model for assessing the readiness level of technology for transfer, as shown in Fig. 1).

Considering that the main nine stages within each of the estimation blocks $\left(a_{1}=5\right)$ within the model are between the zero and the first levels of the hierarchically branched system, a generating function is created to determine the readiness level of technologies for the transfer. This generating function is advisable to use when detecting the readiness level of technologies at the second level of the conceptual model (Fig. 1). Thus, the expression for the generating function is:

$$
S_{1}(z)_{s y m}=P_{0}\left(P_{1} z+q_{1}\right)^{5}+q_{0} .
$$

Having carried out the corresponding mathematical transformations, let's obtain:

$$
\begin{aligned}
& S_{1}(z)_{\text {sym }}=P_{0}\left(P_{1} z+q_{1}\right)^{5}+q_{0}= \\
& =P_{0}\left(\begin{array}{l}
P_{1}^{5} z^{5}+5 P_{1}^{4} z^{4} q_{1}+10 P_{1}^{3} z^{3} q_{1}^{2}+ \\
+10 P_{1}^{2} z^{2} q_{1}^{3}+5 P_{1} z q_{1}^{4}+q_{1}^{5}
\end{array}\right)+q_{0}= \\
& =P_{0} P_{1}^{5} z^{5}+5 P_{0} P_{1}^{4} z^{4} q_{1}+10 P_{0} P_{1}^{3} z^{3} q_{1}^{2}+ \\
& +10 P_{0} P_{1}^{2} z^{2} q_{1}^{3}+5 P_{0} P_{1} z q_{1}^{4}+P_{0} q_{1}^{5}+q_{0} .
\end{aligned}
$$

So, the probabilities of the work of the corresponding quantities of elements (the passage of the stages of technology readiness) will be:

$$
\begin{aligned}
& P_{1}(5)=P_{0} P_{1}^{5} ; P_{1}(4)=5 P_{0} P_{1}^{4} q_{1} ; P_{1}(3)=10 P_{0} P_{1}^{3} q_{1}^{2} ; \\
& P_{1}(2)=10 P_{0} P_{1}^{2} q_{1}^{3} ; P_{1}(1)=5 P_{0} P_{1} q_{1}^{4} ; P_{1}(0)=P_{0} q_{1}^{5}+q_{0} .
\end{aligned}
$$

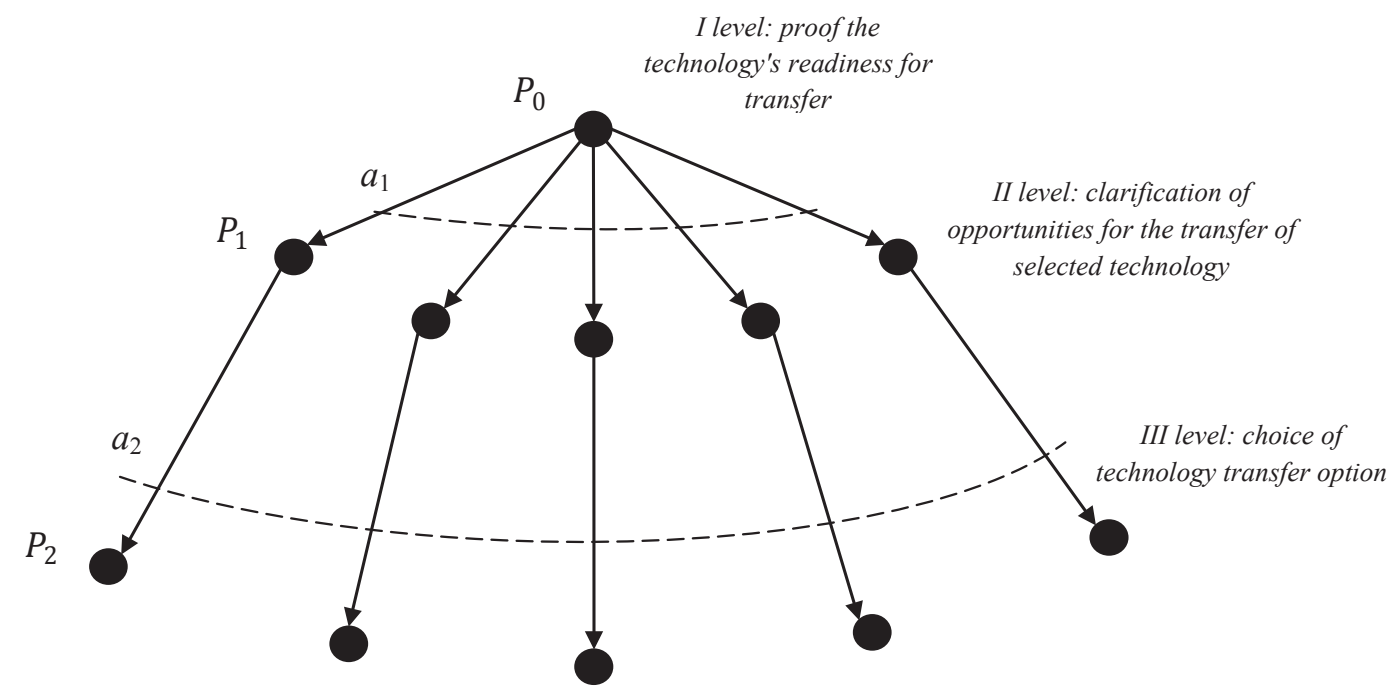

Fig. 4. Hierarchically branched model for assessing the level of technology readiness for a transfer 
In this case, according to the theory of probability, the condition is preserved:

$$
P_{1}(5)+P_{1}(4)+P_{1}(3)+P_{1}(2)+P_{1}(1)+P_{1}(0)=1 .
$$

Accordingly, the mathematical expectation of the number of output working elements in this system can be determined from the expression:

$$
M\left(x_{1}\right)=P_{0} P_{1} a_{1} .
$$

Given that the proposed conceptual model for assessing the readiness level of technologies for a transfer is symmetric, branched to the second level $\left(P_{0}, P_{1}, P_{2}\right)$, and the number of branches is five on the first $\left(a_{1}=5\right)$ and five on the second $\left(a_{2}=5\right)$ levels, let's construct a branched common generating function for the given model:

$$
\begin{aligned}
& S_{2}(z)_{s y m}=P_{0}\left(P_{1}\left(P_{2} z+q_{2}\right)^{a_{5}}+q_{1}\right)^{a_{5}}+q_{0}= \\
& =P_{0} \sum_{x_{1}=0}^{a_{5}} C_{a_{5}}^{x_{1}} \cdot P_{1}^{x_{1}} \cdot q_{1}^{a_{5}-x_{1}}\left(P_{2} z+q_{2}\right)^{a_{5} x_{1}}+q_{0}= \\
& =P_{0} \sum_{x_{1}=0}^{a_{5}} C_{a_{5}}^{x_{1}} \cdot P_{1}^{x_{1}} \cdot q_{1}^{a_{5}-x_{1}} \sum_{x_{2}=0}^{a_{5} x_{1}} C_{a_{5} x_{1}}^{x_{2}} \cdot P_{2}^{x_{2}} \cdot q_{2}^{a_{5} x_{1}-x_{2}}+q_{0} .
\end{aligned}
$$

Proceeding from the above, the recurrence expression for this system of the model for assessing the readiness level of technologies for transfer will be:

$$
P_{2} \underset{x_{2} \geq 1}{\left(x_{2}\right)}=P_{0} \cdot \sum_{x_{1} \geq E\left[\frac{x_{2}}{a_{5}}\right]}^{a_{5}} C_{a_{1}}^{x_{1}} P_{1}^{x_{1}} q_{1}^{a_{5}-x_{1}} \cdot C_{a_{5} x_{1}}^{x_{2}} P_{2}^{x_{2}} q_{2}^{a_{5} x_{1}-x_{2}}
$$

where $E\left[\frac{x_{2}}{a_{5}}\right]=$ ceil $\left(\frac{x_{2}}{a_{5}}\right)-$ closest to $\frac{x_{2}}{a_{2}}$ a larger number.

The recurrent expression for the probability distribution of the original elements will have the form:

$$
P_{2}(0)=P_{2}\left(x_{2}=0\right)+q_{0}
$$

The method of determination of the mathematical expectation is chosen by the reliability distribution:

$$
M\left(x_{2}\right)=\left.\frac{\partial S_{2}(z)}{\partial z}\right|_{z=1}=a_{5} P_{0}(1)^{a_{5}-1} a_{5} P_{1}(1)^{a_{5}-1} P_{2}=a_{5}^{2} P_{0} P_{1} P_{2}
$$

It is worth noting that in each individual case, the evaluation of a particular stage is determined individually and only for a specific technology. This is due to the individual characteristics and features of each technology. Separate technologies do not require mandatory passage of some stages, since the complexity of their evaluation may outweigh other stages.

Let's note that $P_{0}=1$, since at the zero level, when the technology is accepted for consideration, let's assume that the probability of the variant of its successful completion to the transfer is 1 , the probability of the option of nontransfer is $\left(q_{0}=0\right)$.

The proposed method for assessing the level of technology readiness for a transfer based on the reliability theory of hierarchically branched systems is based on the development of:
- a branched generating function for the system of a conceptual model for assessing the readiness level of technology for transfer;

- a recurrence expression for calculating the probability distribution of the number of output working elements of a system of a conceptual model for assessing the readiness level of technology for transfer;

- a mathematical expectation of the number of output working elements of the system of a conceptual model for assessing the readiness level of technology for transfer.

For practical approbation of the proposed toolkit, innovative technology of individual passive dosimetry of ionizing radiation, developed by scientists of the National University «Lviv Polytechnic», is used. This technology is considered by the stages of its readiness, according to the proposed model (Fig. 1). Applying the initial data on this technology and using the expressions (7), (9) and (10), with the help of a computer, appropriate calculations of the level of technology readiness for the transfer are carried out. According to the results of calculations, the indicator of mathematical expectation of technology readiness for the transfer is $69.23 \%$. The adequacy of the obtained index is also confirmed by the results obtained with the use of the method of constructing polygons.

The obtained indicator indicates the average readiness level of technology for the transfer. The most «processed» sides of the technology, according to the proposed model, are «consumer value» and «competitiveness». The weak side is «technological readiness», because at present this technology is at one of the $R \& D$ stages.

The subject of further scientific and practical work is the development of a matrix for selecting options for business forms of technology transfer (depending on the obtained values of indicators according to the proposed methodological tools).

\section{SWOT analysis of research results}

Strengths. Strengths of methodological approaches to assessing the readiness of technology for transfer include:

- increased level of accuracy of the obtained estimates;

- ability to establish the nature of the interaction of the elements of the system among themselves on the basis of recurrent expressions, on the basis of which to draw conclusions about the level of technology development and the specifics of both its evaluation and transfer.

Weaknesses. Methods need to be built into a somewhat outdated traditional model of assessing the readiness of technology for transfer.

Opportunities. Development of these methodological approaches in the development of time and other parameters for assessing the readiness level of technologies within the proposed system.

Threats. The subjectivity of assessments in terms of the use of expert methods is possible.

\section{Conclusions}

1. Based on the analysis of the heritage of scientists in the field of economic assessment of technology readiness for transfer, it can be concluded that existing methods and models are mainly based on the sectoral or local 
nature of the transfer. There is a methodological support for the authorship of Ukrainian researchers aimed at assessing the technology transfer to a particular industry or even an enterprise. At present, there is no necessary and sufficient number of methodological approaches to assessing the readiness level of technology for transfer from universities to the business environment. Foreign works on this problem are of scientific and practical value and are of interest, since for application in Ukrainian conditions they need careful adaptation.

2. A model for assessing the readiness level of technologies for transfer is proposed. The model contains five blocks of technology assessment (consumer value, competitiveness, technological readiness, cost, risk), each of which consists of nine stages of assessing the readiness of technology for transfer. The proposed model should provide an understanding of the subject of technology transfer as the relationship between its participants in the creation and transfer of value added in the form of technology, taking into account the impact of world technological development.

The model is a new concept for assessing the readiness level of technologies for transfer and provides a new approach to the rationale for its methodological tools.

3. A methodological toolkit for assessing the readiness level of technology for transfer based on the reliability theory of hierarchically branched systems is developed. The toolkit is based on the application of:

- branched generating function;

- a recursive expression for calculating the probability distribution of the number of output working elements of the system (allows to establish the nature of the interaction of the elements among themselves, on the basis of which to draw conclusions about the level of technology development and the features of both its evaluation and transfer);

- the mathematical expectation of the number of output working elements for the system for assessing the readiness level of technology for the transfer.

The application of the reliability theory of hierarchically branched systems within the framework of the conceptual model of assessing the readiness level of technology for transfer allows:

- to increase the level of accuracy of the integrated indicator of technology readiness for the transfer;

- to develop a number of other parameters for assessing technology within the proposed system.

\section{References}

1. Schwab, K. The Global Competitiveness Report 2016-2017 [Text]: Report / ed. by K. Schwab. - Geneva: World Economic Forum, 2017. - 400 p. - Available at: \www/URL: http:// www3.weforum.org/docs/GCR2016-2017/05FullReport/TheGlobalCompetitivenessReport2016-2017 FINAL.pdf

2. Baller, S. The Global Information Technology Report 2016: Innovating in the Digital Economy [Text]: Report / ed. by S. Baller, S. Dutta, B. Lanvin. - Geneva: World Economic Forum, 2017. - 307 p. - Available at: \www/URL: http://www3. weforum.org/docs/GITR2016/WEF GITR Full Report.pdf

3. Friedman, J. University technology transfer: do incentives, management and locations matter? [Text] / J. Friedman, J. Silberman // The Journal of Technology Transfer. - 2003. Vol. 28, No. 1. - P. 17-30. doi:10.1023/a:1021674618658

4. Naukova ta innovatsiina diialnist Ukrainy [Text]. - Kyiv: Derzhavna sluzhba statystyky Ukrainy, 2016 - 257 p.

5. Andriesson, D. Implementing the KPMG Value Explorer [Text] / D. Andriesson // Journal of Intellectual Capital. - 2005. Vol. 6, No. 4. - P. 474-488. doi:10.1108/14691930510628771
6. Brooking, A. The predictive potential of intellectual capital [Text] / A. Brooking, P. Board, S. Jones // International Journal of Technology Management. - 1998. - Vol. 16, No. 1-3. P. 115. doi:10.1504/ijtm.1998.002646

7. Bell, D. The Coming Of Post-Industrial Society [Text] D. Bell. - New York: Basic Books, 1976. - 616 p.

8. Brooking, A. Intellectual Capital [Text] / A. Brooking. - Stamford: International Thomson Business Press, 1998. - 213 p.

9. Edvinsson, L. Intellectual Capital: Realizing Your Company's True Value by Finding Its Hidden Roots [Text] / L. Edvinsson, M. Malone. - New York: Harper Collins Publishers, Inc., 1997. - 225 p.

10. Bercovitz, J. Entpreprenerial Universities and Technology Transfer: A Conceptual Framework for Understanding KnowledgeBased Economic Development [Text] / J. Bercovitz, M. Feldman // The Journal of Technology Transfer. - 2005. - Vol. 31, No. 1. - P. 175-188. doi:10.1007/s10961-005-5029-z

11. Chen, J. K. C. Evaluating global technology transfer research performance [Text] / J. K. C. Chen, W.-H. Chiu, S. F. L. Kong, L. Y. T. Lin // 2010 7th International Conference on Service Systems and Service Management. - 2010. doi:10.1109/ icsssm.2010.5530213

12. Fink, K. Knowledge Potential Measurement and Uncertainty [Text] / K. Fink. - Wiesbaden: Deutscher Universitätsverlag, 2004. - 271 p. doi:10.1007/978-3-322-81240-7

13. Hall, B. H. Using patent data as indicators [Text] / B. H. Hall. OST Paris - Patents as Indicators, April, 2014. - 36 p.

14. Kamiyama, S. Business performance and intellectual assets: background and issues [Electronic resource] / S. Kamiyama, C. Martinez, J. Sheehan. - Available at: \www/URL: https:// www.oecd.org/sti/sci-tech/33848005.pdf

15. Kaplan, R. S. The Balanced Scorecard [Text] / R. S. Kaplan, D. P. Norton // Harvard Business Review. - 1996. - Vol. 74, No. 1. - P. 75-85.

16. Lanjouw, J. O. How to Count Patents and Value Intellectual Property: The Uses of Patent Renewal and Application Data [Text] / J. O. Lanjouw, A. Pakes, J. Putnam // Journal of Industrial Economics. - 1998. - Vol. 46, No. 4. - P. 405-432. doi:10.1111/1467-6451.00081

17. Livson, B. Knowledge Capital Valuation [Electronic resource] / B. Livson. - 1987-2009. - Available at: \www/URL: http:/ bal.com.au/knowledge.pdf

18. Luthy, D. H. Intellectual capital and its measurement [Text] / D. H. Luthy. - College of Business, Utah State University, 1998. - $18 \mathrm{p}$

19. Stewart, T. A. Intellectual Capital: The New Wealth of Organizations [Text] / T. A. Stewart. - Crown Business, 1998. - 320 p.

20. Sullivan, P. H. Profiting from Intellectual Capital: Extracting Value from Innovation [Text] / P. H. Sullivan. - Canada: John Wiley and Sons, Inc., 1998. - 369 p.

21. Erik Sveiby, K. The Intangible Assets Monitor [Text] / K. Erik Sveiby // Journal of Human Resource Costing \& Accounting. 1997. - Vol. 2, No. 1. - P. 73-97. doi:10.1108/eb029036

22. Pererva P. H. Monitorynh innovatsiinoi diialnosti: interpretatsiia rezultativ [Text] / P. H. Pererva, I. V. Hladenko // Marketynh i menedzhmenti innovatsii. - 2010. - No. 2. - P. 108-116.

23. Kozyk, V. V. Aktualizatsiia roli transferu tekhnolohii u systemi «universytet - vlada - biznes» v Ukraini [Text] / V. V. Kozyk, O. B. Mrykhina // Visnyk Kyivskoho natsionalnoho universytetu tekhnolohii ta dyzainu. Seriia: Ekonomichni nauky. - 2017. No. 2 (109). - P. 29-35.

24. Illiashenko, S. M. Intelektualnyi kapital VNZ yak zaporuka yoho innovatsiinoho rozvytku: sutnist, struktura, pidkhody do otsinky [Text] / S. M. Illiashenko // Menedzhment i marketynh innovatsii. - 2011. - No. 1. - P. 145-154.

25. Yastremska, O. M. Upravlinnia innovatsiinoiu diialnistiu [Text] Monograph / O. M. Yastremska, H. V. Vereshchahina. - Kharkiv: FOP Pavlenko O. H., VD «INZhEK», 2010. - 404 p.

26. Sytnyk, Y. S. Teoretyko-metodolohichni zasady intelektualizatsii menedzhmentu pidpryiemstva [Text]: Monograph / Y. S. Sytnyk. Lviv: Vydavnytstvo Lvivskoi politekhniky, 2011. - 328 p.

27. Shpak, N. O. Osnovy komunikatsiinoho menedzhmentu promyslovykh pidpryiemstv [Text]: Monograph / N. O. Shpak. Lviv: Vydavnytstvo Lvivskoi politekhniky, 2014. - 248 p.

28. Dovbenko, V. I. Rol potentsialu transferu znan i tekhnolohii v innovatsiinomu protsesi [Text] / V. I. Dovbenko // Visnyk Natsionalnoho universytetu «Lvivska politekhnika». Menedzhment 
ta pidpryiemnytstvo v Ukraini: etapy stanovlennia i problemy rozvytku. - 2013. - No. 776. - P. 254-263.

29. Yemelianov, O. Yu. Metodychni zasady otsiniuvannia ekonomichnoi efektyvnosti vprovadzhennia resursozberihaiuchykh tekhnolohii na promyslovykh pidpryiemstvakh [Text] / O. Yu. Yemelianov, T. O. Petrushka, I. Z. Kret // Visnyk Natsionalnoho universytetu «Lvivska politekhnika». Problemy ekonomiky ta upravlinnia. - 2013. - No. 754. - P. 18-25.

30. Solovii, Kh. Ya. Balanced indicator system as an effective tool for objectively assessing the effectiveness of enterprise innovation [Text] / Kh. Ya. Solovii // Actual problems of the economy. - 2010. - No. 1 (103). - P. 155-163.

31. Mrykhina, O. B. The methodical and regulatory framework of technology transfer [Text] / O. B. Mrykhina, A. R. Stoianovskyi, T. I. Mirkunova // Problems of economics. - 2015. - No. 1. P. $126-132$

32. Marunchak, D. Ye. Nadiinist rozghaluzhenykh system [Text]: Handbook / D. Ye. Marunchak, A. R. Sydor. - Lviv: Vydavnytstvo Lvivskoi politekhniky, 2007. - 124 p.

\section{ОБОСНОВАНИЕ МЕТОДИЧЕСКИХ ПОДХОДОВ К ОЦЕНКЕ ГОТОВНОСТИ ТЕХНОЛОГИЙ К ТРАНСФЕРУ}

Исследованы методы и модели экономической оценки трансфера технологий. Предложена модель оценки уровня готовности технологий к трансферу, состоящая из пяти оценочных блоков (потребительская ценность; конкурентоспособность; технологическая готовность; затратность; рискованность). Разработан методический инструментарий для оценки уровня готовности технологий к трансферу на основе теории надежности иерархически разветвленных систем.

Ключевые слова: методы и модели экономической оценки, трансфер технологий, теория надежности иерархически разветвленных систем.

Kozyk Vasyl, PhD, Professor, Head of the Department of Economics of Enterprises and Investments, Lviv Polytechnic National University, Ukraine, e-mail:vasyl.v.kozyk@gmail.com, ORCID: https://orcid.org/ 0000-0003-4204-6026

Mrykhina Oleksandra, PhD, Associate Professor, Department of Economics of Enterprises and Investments, Lviv Polytechnic National University, Ukraine, e-mail: oleksandramrykhina@gmail.com, ORCID: https://orcid.org/0000-0002-0567-2995

Mirkunova Tamara, Postgraduate Student, Department of Economics of Enterprises and Investments, Lviv Polytechnic National University Ukraine, e-mail: tamaramirkunova479@gmail.com,ORCID: https:// orcid.org/0000-0003-1772-0445

Stashchuk 0. RESEARCH OF THE SOURCES
OF MACROECONOMIC THREATS OF
FINANCIAL SECURITY OF JOINT STOCK
COMPANIES

Проведено аналіз підходів до виокремлення загроз фінансової безпеки суб'єктів господарювання. Доведено виникнення зовнішніх та внутрішніх загроз фінансової безпеки акціонерних товариств у формі дестабілізачійного впливу або у формі детермінант фінансової безпеки корпоративних структур. Систематизовано макроекономічні загрози фінансової безпеки акціонерних товариств відповідно до законодавства України. Виявлено основні джерела зовнішніх загроз корпоративних структур за сферами їх впливу.

Ключові слова: макроекономічні загрози, фінансова безпека, акціонерні товариства, фінансова політика, фінансова система, джерела виникнення загроз.

\section{Introduction}

Reproductive processes in the Ukrainian economy are characterized by the destabilizing influence of a certain set of threats and dangers. What is stronger is the power of their influence on the efficiency of the functioning of both individual joint-stock companies and the country's economy as a whole. The strength of the influence of such phenomena determines the level of financial security of corporate structures, and is accompanied by a decrease in the resistance of economic agents to macroeconomic factors. The aim of a comprehensive study of the specifics of ensuring financial security of joint-stock companies is identification of their macroeconomic threats. The lack of a unified approach to the allocation of macroeconomic threats to the financial security of joint stock companies among the world's scientific needs further research on the problem of ensuring the necessary level of financial security by corporate structures, and this research is actualized.

\section{The object of research and its technological audit}

The object of research is the financial security of jointstock companies in Ukraine.

In order to achieve the necessary level of financial security by the joint-stock companies, as well as minimize the factors of destructive influence on the effectiveness of their financial activities, separate studies have been carried out on this issue. In the Ukrainian legislation, namely [1-3]:

- in the National Security Strategy of Ukraine;

- in the Law of Ukraine «On the Fundamentals of

National Security of Ukraine»;

- in the Concept of Financial Security of Ukraine. 